
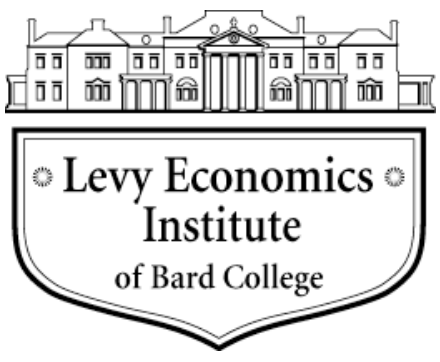

Working Paper No. 846

\title{
Secular Stagnation or Stagnation Policy? Steindl after Summers
}

by

\author{
Eckhard Hein \\ Levy Economics Institute of Bard College
}

October 2015

\begin{abstract}
* Paper presented at the Fifth Graz Schumpeter Summer School, "Economic Stagnation: Problems of Theory and Policy-From Malthus to Piketty," July 12-18, 2015. For helpful comments I am grateful to the participants, and to Daniel Detzer and Jan Priewe in particular. For editing assistance, I would like to thank James Masterson. Remaining errors are, of course, mine.

$\$$ Professor of Economics, Berlin School of Economics and Law, Badensche Str. 52,10825 Berlin, Germany; eckhard.hein@hwr-berlin.de
\end{abstract}

The Levy Economics Institute Working Paper Collection presents research in progress by Levy Institute scholars and conference participants. The purpose of the series is to disseminate ideas to and elicit comments from academics and professionals.

Levy Economics Institute of Bard College, founded in 1986, is a nonprofit, nonpartisan, independently funded research organization devoted to public service. Through scholarship and economic research it generates viable, effective public policy responses to important economic problems that profoundly affect the quality of life in the United States and abroad.

Levy Economics Institute

P.O. Box 5000

Annandale-on-Hudson, NY 12504-5000

http://www.levyinstitute.org

Copyright (C) Levy Economics Institute 2015 All rights reserved

ISSN 1547-366X 


\begin{abstract}
The current debate on secular stagnation is suffering from some vagueness and several shortcomings. The same is true for the economic policy implications. Therefore, we provide an alternative view on stagnation tendencies based on Josef Steindl's contributions. In particular, Steindl (1952) can be viewed as a pioneering work in the area of stagnation in modern capitalism. We hold that this work is not prone to the problems detected in the current debate on secular stagnation: It does not rely on the dubious notion of an equilibrium real interest rate as the equilibrating force of saving and investment at full employment levels, in principle, with the adjustment process currently blocked by the unfeasibility of a very low or even negative equilibrium rate. It is based on the notion that modern capitalist economies are facing aggregate demand constraints, and that saving adjusts to investment through income growth and changes in capacity utilization in the long run. It allows for potential growth to become endogenous to actual demand-driven growth. And it seriously considers the role of institutions and power relationships for long-run growth — and for stagnation.
\end{abstract}

Keywords: Secular Stagnation; Stagnation Policy; Distribution and Growth; Steindl JEL Classifications: B22, E11, E12, E65, O11 


\section{INTRODUCTION}

After the financial crisis and the Great Recession of 2008/09, the EU and Euro area in particular, but also Japan and even the US, have seen only weak recoveries. Therefore, the issue of long-run stagnation, or of "secular stagnation" (that is: low or even negative growth over a prolonged period of time), seems to be on the agenda (again) for academic economists, economic policy advisers, and policymaking institutions. Commonly, the start of the debate is associated with the contribution by Summers (2013) to the IMF Economic Forum and a follow-up paper, in which he argues that "the trend in growth can be adversely affected over the longer term by what happens in the business cycle" (Summers 2014a, 66). The Great Recession might therefore have caused a "secular stagnation" for the years to come. This has triggered a debate on a tendency towards secular stagnation in developed capitalist economies, as has recently been documented by the contributions to Teulings and Baldwin (2014a), for example. This debate has forwarded both demand- and supply-side arguments regarding the pros and cons of secular stagnation. However, as Teulings and Baldwin (2014b) point out, a "fairly strong consensus" has emerged, according to which secular stagnation may be defined as a state of the economy in which negative real interest rates in the capital market are required in order to establish an equilibrium of saving and investment. This makes it much harder for central banks facing the zero lower bound for nominal interest rates under their control to achieve full employment with low inflation.

What is puzzling in the current debate on secular stagnation is the almost complete absence of any references to the history of economic thought on this issue, as Backhouse and Boianovsky (2015) have reminded us recently. Of course, tribute is usually paid to Hansen (1939) who discussed the tendencies towards secular stagnation against the background of the Great Depression in the US of the 1930s and who identified three fundamental causes for stagnation: declining population growth, changes in the character of technological progress, and the falling availability of new territory in the US. ${ }^{1}$ However, whereas Hansen (1939) had at least referred to the works of Smith, Ricardo, and Malthus, in the modern contributions there are no longer any such references or discussions. Consequently, it comes as no big surprise that contributions by heterodox authors on stagnation tendencies in modern capitalism, as for example by Hobson (1902), Luxemburg (1913), Sweezy (1942), Keynes (1943), Steindl (1952), Kalecki (1954, chapter 15; 1971, chapter 13), and Baran and Sweezy

\footnotetext{
${ }^{1}$ Gordon (2014) has pointed out that the term "secular stagnation" had already been invented by Hansen (1934).
} 
(1966), are completely ignored as well. ${ }^{2}$ The same holds true for modern interpretations and applications of these approaches.

This is a problem, because the theoretical foundations of modern secular stagnation debates are vague and can be challenged on several grounds. First, as is clear from the consensus proclaimed by Teulings and Baldwin (2014b) mentioned above, at the very foundations, even of the presumably more Keynesian work by Summers (2014a, 2014b, 2015), Krugman (2014), and others, in principle, we have an equilibrium real or natural rate of interest equalizing saving and investment in the capital market at full employment output levels, which, however, may not be feasible. This constellation is vulnerable to critique from the "Cambridge controversies in the theory of capital," questioning an interest rate-inverse and continuously downward sloping capital demand curve in a more-than-one-good economy, as well as the Keynesian critique with respect to the causalities between and adjustments of saving and investment in a monetary production economy. Second, most of the mainstream literature on secular stagnation seems to assume that the natural or potential rate of growth is more or less independent of aggregate demand dynamics, thus ignoring potential feedback and endogeneity channels. And third, in the modern discussion on secular stagnation changes in institutions and power relationships between social classes, as witnessed in the rise of finance-dominated capitalism over the last three decades or so, does not seem to have an important role to play at all. Therefore, some of the policy recommendations on how to deal with secular stagnation proposed in the recent literature can also be considered to be highly problematic or at least incomplete.

Given the shortcomings in the current debate on secular stagnation, this paper will provide the foundations of an alternative view on stagnation tendencies based on the works of Josef Steindl, which is not exposed to the problems mentioned above - in a sense "Steindl after Summers." However, from what has been said so far, the purpose cannot be to reinterpret and improve Steindl's approach against the background of Summers's and other more recent contributions. We hope, rather, to present a theoretically more solid alternative perspective on stagnation, stagnation policy, and requirements for anti-stagnation policy, acknowledging that the contributions by Summers and others have opened the door for debate. ${ }^{3}$ In section 2, we will review the current debate on secular stagnation and its economic policy implications in more detail. Section 3 will then turn to Steindl's (1952)

\footnotetext{
${ }^{2}$ For overviews see, for example, Bleany (1976) on the history of underconsumption and stagnation theories, Foster $(1987,2014)$ and Foster and McChesney (2012) on Marxian theories of monopoly capitalism and stagnation, and Hein (2014, chapter 5) on Kalecki's and Steindl's contributions.

${ }^{3}$ The general purpose is thus different from Ian Steedman's (1977) Marx after Sraffa, which has inspired our subtitle.
} 
"maturity and stagnation" approach and section 4 will provide a simple model of distribution, growth, and stagnation based on Steindl's contributions. Based on this model, section 5 will then address the role of institutions, power relationships, and economic policies, explaining why stagnation in the 1950s and 1960s did not materialize, but why stagnation tendencies have become more prevalent again since the 1980s, in particular because of "stagnation policy" and the rise of finance-dominated capitalism, and to what extent stagnation tendencies will have to be faced in the future. Section 6 will briefly address economic policy implications and section 7 will conclude.

\section{THE CURRENT DEBATE ON SECULAR STAGNATION AND ITS SHORTCOMINGS}

Teulings and Baldwin (2014b) have conveniently structured the current (mainstream) debate on secular stagnation and we can follow their structure in our brief outline here. First, they distinguish approaches that rest on those factors which are supposed to affect the economy's long-run potential growth rate. Second, they have those approaches that focus on the deviation of actual growth from potential growth. Third, there are those approaches focusing on one-off changes in the level of GDP, shifting the long-run growth path downwards.

The first approach towards secular stagnation, arguing that potential growth has come down, refers to lower growth of factor inputs and/or lower growth in innovations and technological knowledge about the combination of factor inputs. Regarding the latter, there seems to be some agreement that there is no good reason to assume a secular decline in the creativity of mankind and the ability to innovate. ${ }^{4}$ And regarding the former, there seems to be broad agreement that developed capitalist economies are facing stagnant and aging populations, which reduces labor supply growth. Furthermore, Gordon $(2012,2014)$ has argued that for the US the mass education revolution is complete, and therefore no further increase in the average US education level boosting productivity growth is to be expected. This might also hold for several other advanced capitalist economies. ${ }^{5}$

The second approach argues that growth is and will be below potential growth. This is, in particular, the core of Summers's $(2013,2014 a, 2014 b, 2015)$ argument. ${ }^{6}$ And the main

\footnotetext{
${ }^{4}$ As Gordon $(2014,52)$ puts it: "In my numbers, there is no forecast of a future technological slowdownproductivity growth adjusted for educational stagnation is predicted to be just as fast during 2007-2032 as during 1972-2007." See also the contributions by Crafts (2014), Glaeser (2014), and Mokyr (2014).

${ }^{5}$ Gordon (2014) also discusses rising income inequality and rising government debt-GDP ratios as "headwinds" that each constrain the future after tax income growth for the bottom 90 or 99 percent of the US population.

${ }^{6}$ See also Blanchard, Furceri, and Pescatori (2014) and Krugman (2014) for similar arguments.
} 
reason for this is a substantial decline in the "equilibrium," "normal," "natural," or "fullemployment" real interest rate equilibrating saving and investment:

I shall argue three propositions. First, as the United States and other industrial economies are currently configured, simultaneous achievement of adequate growth, capacity utilization, and financial stability appears increasingly difficult. Second, this is likely to be related to a substantial decline in the equilibrium or natural real rate of interest. Third, addressing these challenges requires different policy approaches than are represented by the current conventional wisdom. (Summers 2014a, 66; my emphasis)

I would suggest that in understanding this phenomenon, it is useful at the outset to consider the possibility that changes in the structure of the economy have led to a significant shift in the natural balance between savings and investment, causing a decline in the equilibrium or normal real rate of interest that is associated with full employment. (Summers 2014a, 69; my emphasis)

Low or even negative equilibrium real interest rates make it much harder for central banks, facing the zero lower bound for short-term nominal interest rates under their control, to achieve full employment under the conditions of low inflation applying traditional inflation targeting interest rate policies, as advocated by new consensus macroeconomics before the crisis. Furthermore, extremely low interest rates, plus central banks applying unconventional measures, increase the risks of financial instability. ${ }^{7}$ Policymakers thus seem to face the choice between stagnation or highly unstable bubble growth, as in the 2003-07 period in the US (Summers 2014b).

In the current debate the causes for low or negative equilibrium real interest rates are related to the demand for and the supply of loanable funds, as well as to changes in risk assessments and an overall higher preference for safe assets. ${ }^{8}$ Summers $(2014 \mathrm{a}, 2014 \mathrm{~b})$ has provided the following arguments: the demand for loanable funds has declined because of low inducements to investment, due to deleveraging after the crisis; ${ }^{9}$ low real capital stock requirements in order to start business in the growing sectors of the economy, in particular in

\footnotetext{
${ }^{7}$ Summers (2014b) mentions three reasons why low interest rates raise financial instability: increasing risktaking; promotion of irresponsible lending as debt services seem to be low and easy to meet; and higher attractiveness of Ponzi financial structures because interest rates look low relative to expected growth rates. ${ }^{8}$ See also Blanchard, Furceri, and Pescatori (2014) and Krugman (2014) on too low equilibrium real interest rates as causes for stagnation. Eggertson and Mehrotra (2014a, 2014b) provide and elaborate on a New Keynesian model with overlapping generations, in which a stagnation is possible without any forces driving the economy back to full employment. The trigger in the model is a deleveraging shock, which creates an oversupply of savings. A drop in population growth, an increase in income inequality, and a fall in the relative price of investment can also cause stagnation in the model.

${ }^{9}$ This is Koo's $(2013,2014)$ argument, who relates stagnation to deleveraging of the private sectors, which is not compensated for by the required deficits in the public sectors. This constellation then forces economic activity down.
} 
ICT; and decreases in relative prices of capital goods. Declining population growth and ageing societies have also reduced the demand for loanable funds, in particular for capital stock and housing finance, and have increased the supply of funds in those countries with a capital-funded pension system. The supply of loanable funds has also increased because of rising inequality in wealth and income distribution. Increasing shares of income going to high income households with a lower marginal propensity to consume and rising retained earnings of corporations have meant a rise in the average propensity to save for the economy as a whole. Finally, global tendencies to shift accumulated savings to safe havens have further lowered the equilibrium real interest rate in countries like the US. This has been reinforced by tightened regulatory requirements for pension funds, banks, and insurance companies to increase their holdings of safe assets.

The third approach explains a lower growth path after a severe recession. The major reason for this is labor market hysteresis. Empirically, however, this channel seems to be relevant only for the US, but not for other countries, if labor force participation rates are taken as an indicator; some of the European countries suffering most from the euro crisis rather show a cyclical downturn but no ratchet effect in long-run comparison (Teulings and Baldwin 2014b). And theoretically, this approach does not explain a lower rate of growth, usually associated with secular stagnation. Feedback effects of low actual growth on potential growth rates have not been systematically explored in this context - although Summers (2014b, 37) indicates this possibility: "Perhaps Say's dubious law has a more legitimate corollary_ _Lack of Demand creates Lack of Supply."”

Policy implications of the current secular stagnation literature, of course, differ with respect to the main causes of stagnation the authors consider to be important. ${ }^{10}$ Authors, who hold that the decline in potential growth is the major problem, advocate measures boosting potential growth without caring much about detrimental effects on demand and actual growth. These measures include policies to raise labor supply and hours worked, as well as policies that are assumed to stimulate innovation and increase efficiency. Teulings and Baldwin (2014b) list the following suggestions: improving the education system; investing in the physical infrastructure; removing barriers for labor mobility between firms by reducing employment protection legislation; increasing incentives for low-skilled workers to participate in the labor market; simplifying procedures for starting up businesses; and applying anti-monopoly policies to reduce the profit margins in new ICT industries. Of

\footnotetext{
${ }^{10}$ The OECD (2015), for example, suggests a combination of both demand- and supply-side measures, with a focus on the latter. Accommodative monetary and fiscal policies accompanied by structural reforms are advocated in general. Four main areas for structural reform are singled out: promotion of investment; SMEs and entrepreneurship; trade; and employment activation.
} 
course, some of these measures will also be favorable for demand and actual growth, like infrastructure investment or anti-monopoly policies; however, deregulations of the labor markets are likely to increase pressure on labor and to further worsen income distribution, decrease confidence, and thus reduce aggregate demand growth.

For those authors who consider the deviation of actual output growth from potential growth to be the major problem, like Summers (2014a, 2014b, 2015), Blanchard, Dell'Ariccia, and Mauro (2010), Blanchard, Furceri, and Pescatori (2014), Koo (2014), and Krugman (2014), adequate and consistent demand management is of utmost importance. Since a very low or even negative equilibrium real interest rate is the major problem, the room to maneuver for central banks to bring real interest rates down would have to be increased. This includes raising the inflation target, which alleviates the zero lower-bound problem, and applying extensive unconventional measures aiming at gaining better control over long-term interest rates, which are relevant for saving and investment, according to this approach. The downside of this strategy, according to Summers (2014a, 2014b), however, is rising financial instability. Alternatively, Summers (2014a, 2014b, 2015) advocates increasing investment and reducing saving, which will then raise the equilibrium real interest rate. This would include the increase of public investment, prolonged countercyclical fiscal policies and a reduction of barriers for private investment, promotion of business confidence, commitment to basic social protection, and an extension of pay-as-you-go pension and health insurance systems in order to stimulate private consumption spending, as well as income redistribution towards lower income households with a higher propensity to consume. Finally, export promotion, via trade agreements, etc., is recommended. Teulings and Baldwin (2014b) briefly mention further measures, which are said to be in this line, like raising the retirement age in capital-funded pension systems in order to reduce saving, revising regulations that force institutional investors to invest in triple-A assets, and further globalizing financial markets in order to export excess savings from mature to emerging market economies.

In particular the latter measures seem to be quite dubious regarding their effects on sustainable demand growth. However, what is acknowledged in the current debate, particularly by those authors focusing on the deviation of actual growth from potential growth as a cause for stagnation, is the requirement of a complete reform of macroeconomic policymaking. Economic policy tools and strategies, based so far on new consensus macroeconomics, with the central bank interest rate as the main or even only stabilization tool, would have to be rethought completely. On the one hand, inflation targets would have to 
be lifted and central banks would have to apply further measures, like quantitative easing, in order to bring long-term interest rates down. On the other hand, fiscal policies would have to gain tremendously in relevance in comparison to new consensus macroeconomics, which have ignored the stabilizing role of fiscal policies and have imposed some balanced budget over the cycle rules and constraints. Implementing these new recommendations would have major implications for the coordination of fiscal policies in the Euro area, which is to date obsessed with balanced or even surplus public budgets and the reduction of government debtGDP ratios.

Although the contributions by Summers (2014a, 2014b, 2015), Blanchard, Dell'Ariccia, and Mauro (2010), Blanchard, Furceri, and Pescatori (2014), Koo (2014), Krugman (2014), and others have reopened the gate for a discussion of the Keynesian problem and some of the policy implications are consistent with more Keynesian or postKeynesian works, the current debate struggles with several problems.

First, even in the presumably more Keynesian works by Summers (2014a, 2014b, 2015) and others, in principle, we have a real or natural rate of interest equilibrating saving and investment in the capital market at full employment output levels, although this mechanism is currently blocked by the unfeasibility of very low or negative equilibrium real rates of interest. In other words, we have a long-run (notional) equilibrium in which "a dog called savings wag(s) his tail labelled investment" (Meade 1975, 62), and the equilibrating variable is the real rate of interest. This ignores the challenge of the very existence of a uniquely interest rate elastic and downward-sloping capital demand curve in a more-thanone-good economy, as put forward in the "Cambridge controversies on the theory of capital" (Harcourt 1969, 1972; Lazzarini 2011; Hein 2014, chapter 3.6). Furthermore, it ignores the Keynesian challenge that in a monetary production economy "a dog called investment wags his tail called saving" (Meade 1975, 62). In such an economy, saving adjusts to investment, initially financed independently of aggregate saving through a developed financial sector generating money and credit out of nothing. And this is not only true for the short run, but also for long-run growth, as Joan Robinson (1962, 82-83) has famously summarized: "The Keynesian models (including our own) are designed to project into the long period the central thesis of the General Theory, that firms are free, within wide limits, to accumulate as they please, and that the rate of saving of the economy as a whole accommodates itself to the rate of investment that they decree." These long-run macroeconomic adjustments of saving to investment occur via changes in output growth and capacity utilization, the Kalecki/Steindl 
mechanism, and/or through changes in functional income distribution, the Kaldor/Robinson mechanism.

Second, the natural or potential rate of growth in the modern discussions about secular stagnation seems to be more or less independent of aggregate demand dynamics. The only exception is an indirect effect of aggregate demand failures on labor market hysteresis and thus on the level of potential output and on the growth path, but not necessarily on the potential output growth rate. Also, other more direct effects of aggregate demand growth on productivity and hence potential output growth, as suggested by Kaldor's $(1957,1961)$ technical progress function or Kaldor's (1966) Verdoorn's law, are disregarded.

And third, potential stagnation tendencies caused by changes in institutions and power relationships between social classes, such as those associated with the rise of financedominated capitalism over the last three decades or so (Hein 2012a; Foster and McChesney 2012; Palley 2012, 2013), do not seem to have an important role to play at all in the modern discussions on secular stagnation.

Given these theoretical shortcomings, the policy implications outlined above will also have to be considered as either misguided, in particular those exclusively focusing on stimulating potential growth, or as incomplete. In the following sections we will therefore provide an alternative view on stagnation tendencies in mature capitalist economies based on Josef Steindl's contributions. In particular Steindl (1952) can be viewed as a pioneering work in the area of stagnation theories in modern capitalism. We hold that Steindl's work is not prone to the problems detected in the current debate on secular stagnation: It does not rely on a dubious notion of an equilibrium real interest rate equilibrating saving and investment at full employments levels, in principle. It is based on the notion that modern capitalist economies face aggregate demand constraints in the long run, and that saving adjusts to investment also in a growth context. It allows for potential growth to become endogenous to actual demand driven growth. And it seriously considers the role of institutions, power relationships, and economic policies for long-run growth — and for stagnation.

\section{STEINDL'S “MATURITY AND STAGNATION” APPROACH ${ }^{11}$}

Steindl's (1952) view on long-run growth and stagnation contained in his Maturity and Stagnation in American Capitalism, which tried to explain the interwar US development, is built on Kalecki's work on economic dynamics (Hein 2014, chapter 4) on the one hand, and

\footnotetext{
${ }^{11}$ This section partly draws on Hein $(2014,227-234)$.
} 
on the microeconomic analysis provided in the same book on the other hand. ${ }^{12}$ When the book appeared in the early 1950s, to the disappointment of the author, it did not attract much attention:

The first (1952) edition of this book appeared at a time which could not have been less propitious for its success. Neoclassicism reigned in the economics profession. The advanced industrial countries had begun to establish full employment, rapidly rising living standards, and international cooperation; and in this atmosphere of confidence an analysis of the dismal experience of 1929-1939 seemed to be out of place. (Steindl 1976, ix)

But when the "golden age" period of post-World War II capitalism faltered, Steindl's approach gained prominence and had a major impact on the post-Keynesian/Kaleckian theories of distribution and growth. But even before, it was well received by Marxian underconsumptionist theorists of crisis in modern capitalism, and some parallels with, for example, Baran and Sweezy's (1966) Monopoly Capital are apparent (Bleany 1976, chapter 12; Cowling 1982; Lee 1998, chapter 10). ${ }^{13}$

In contrast to Kalecki (1954), Steindl's (1952, part I) important distinction is not between demand- and cost-determined prices, but rather between pricing in competitive industries and in oligopolistic industries. In the competitive industries, profit is treated as a differential rent accruing to the more productive firms in the industry, usually the bigger firms because technological progress is embodied in the capital stock. If the industry is hit by a negative demand shock, marginal firms will be squeezed out by downward price adjustments. Similarly, innovations will temporarily increase profits of the innovative firm, but then the diffusion of the innovation will reduce profits towards some normal level, and during the associated increase in output and the lowering of output prices marginal firms will again be squeezed out. These processes in competitive industries will increase the market shares of the innovative and most productive firms and will thus lead to "absolute concentration" and a tendency towards oligopolistic industries.

In oligopolistic industries, negative demand shocks or technological innovations will not cause prices to fall and marginal firms to be squeezed out, because these firms earn above normal profits, owing to entry barriers given by the minimum capital to be advanced in order to start production in the respective industry, and also to strategic price setting of incumbent firms. Prices remain rigid in these industries, and a decline in demand will mean lower rates of capacity utilization. Because of downward price rigidities, labor-saving technological

\footnotetext{
${ }^{12}$ On Steindl's approach towards pricing, distribution, growth, and other issues, see King (1995), Shapiro (2012), and the contributions in the edited book by Mott and Shapiro (2005).

${ }^{13}$ In fact, the second edition of Maturity and Stagnation in American Capitalism was published in 1976 with Sweezy's Monthly Review Press.
} 
progress will increase mark-ups or profit margins. Furthermore, other types of competition will be applied, in particular marketing efforts and product differentiation.

The tendencies towards oligopoly discovered at the microeconomic level will cause a tendency towards stagnation at the macroeconomic level (Steindl 1952, part II). In his new introduction, Steindl (1976, xv) neatly summarizes his main arguments in Maturity and Stagnation in American Capitalism as follows:

(1) Oligopoly brings about a maldistribution of funds by shifting profits to those industries which are reluctant to use them. [...]

(2) Oligopoly leads to a decline in the degree of utilisation, either by a tendency to increase mark-ups or by a rigidity of the mark-up in face of a decline in investment.

These two developments generate problems of effective demand for the economy as a whole, which will be self-reinforcing and thus may cause long-run stagnation. Because of excess capacity, oligopolies will be increasingly reluctant to invest in their industries, even if profits are constant or rising ("incomplete reinvestment" of retained profits), and firms in competitive industries will lack the internal funds required to expand and to compensate for the stagnative tendencies imposed on the economy by oligopolistic industries.

Any fall in investment and aggregate demand will therefore be self-reinforcing, and cause lower rates of capacity utilization and a further decline in investment and aggregate demand for the economy as a whole, as in Harrod's (1939) instability process (Steindl 1979, 1985). Recall that Harrod's "warranted rate of growth" $\left(g_{w}\right)$ is given by the overall propensity to save (s), the normal or target rate of utilizations of productive capacities $\left(\mathrm{u}_{\mathrm{n}}\right)$, and by the capital-potential output ratio (v), which is considered to be technologically determined and to be independent of growth and the profit rate: $g_{w}=\frac{s u_{n}}{v}($ Hein 2014, chapter 2). As Steindl (1985) explains, lower growth of aggregate demand, falling short of Harrod's "warranted rate," that is $\mathrm{g}<\mathrm{g}_{\mathrm{W}}$, would require a lower propensity to save, and thus lower profit margins and profit rates, in order to avoid the rate of capacity utilization falling below the normal or target rate and hence causing a further slowdown in growth. In other words, it would require redistribution from corporations to households, or from gross profits to wages, assuming the propensity to save out of wages to fall short of the propensity to save out of gross profit.

However, this does not happen because of the price rigidity in oligopolistic industries. This is how Steindl (1985, 157-158) describes it: 


\begin{abstract}
I have discussed in Maturity and Stagnation the conditions for a mechanism by means of which $(1-\lambda)$ [the share of profits, E.H.] would adapt itself to a lowering of the growth rate. It would work through a competitive struggle with the aim of eliminating high cost producers; this would re-establish a normal degree of utilisation and at the same time lower the profit margin. In an industry dominated by oligopolies, however, this mechanism cannot easily work, because the risks and cost of a competitive struggle are much too high. In consequence the oligopolistically organised industry will experience permanent excess capacity if the growth rate falls, with further depressive consequences, since the excess capacity will discourage investment. Using the same assumptions it can be shown that the transition from a competitive to an oligopolistic regime, if it causes an increase in profit margins at a given rate of utilisation, will lead to excess capacity and hence a secular decline in growth.
\end{abstract}

In the case of the dominance of oligopolies, a fall in the rate of capacity utilization can only be prevented by an increase of "external" sources of demand, hence in the government deficit or the export surpluses, as Steindl (1985) points out.

Steindl (1976, xv) acknowledges that the "maldistribution of funds" argument per se is not a strong argument for lower private investment and growth, in the face of multi-branch activities of larger firms, which could invade competitive industries and invest there.

However, low rates of capacity utilization on a broader scale as a deterrent to investment are considered to be the important argument for the maturity and stagnation hypothesis. Another argument, which Steindl addresses in his later publications (Steindl 1964, 1979, 1985), but is not mentioned in his 1952 book, does not relate to oligopoly in particular but to big business in general and says "that the preference for safety increases with size, and that profit is bartered for safety, with a resulting reluctance to go into debt and a consequent weakening of the incentive to invest" (Steindl 1976, xv). This could be interpreted as a decline in "animal spirits," the "spontaneous urge to action rather than inaction" (Keynes 1936, 161), with the increasing size of the firm.

What is also missing in Steindl's 1952 book is a role for technological progress and innovations when it comes to the explanation of long-run trends of capital accumulation and growth. The reason for this is that Steindl wanted to present a theory in which investment is completely endogenous and "net investment is called forth by the stimulus of economic factors, like internal accumulation of business, a high degree of utilization, a high profit rate, or low indebtedness. Innovations, to express this view in its most extreme form, affect only the form which net investment takes" (Steindl 1952, 133; emphasis in the original).

Steindl's (1952) endogenous determination of investment thus includes several arguments, which also figure prominently in Kalecki's theories of investment (Steindl 1981a; Hein 2014, chapter 5.6), like retained profits and indebtedness, referring to the finance constraint implicit in Kalecki's (1937) "principle of increasing risk," and the rate of profit, 
capturing the opposing effects of changes in profits and in the capital stock on investment. Unlike Kalecki, Steindl explicitly includes the rate of capacity utilization, or more precisely the deviation of the realized rate of utilization from some planned rate, into his investment function. Following Steindl $(1952,214)$, firms' decisions to invest thus depend positively on retained profits $\left(\Pi_{\mathrm{F}}\right)$ relative to the nominal capital stock $(\mathrm{pK})$, the capital stock owned by the firm $\left(\mathrm{pK}_{\mathrm{F}}\right)$ relative to the total value of the capital stock - this is the inverse of Steindl's $(1952,46)$ "gearing ratio" $\left(\mathrm{pK} / \mathrm{pK}_{\mathrm{F}}\right)$ - and on the deviation of the realized rate of utilization of productive capacities given by the capital stock from some planned rate $\left(u-u_{0}\right)$.

Technical progress and innovations are absent from this approach, because Steindl held that these are difficult to model and have hence to be treated as exogenous variables. However, in his later publications, Steindl changed his mind, in particular under the impression of Kalecki's work, and argued: "When I wrote Maturity and Stagnation, I wanted to deny all influences of innovations on the accumulation of capital. I think now that this was foolish and I subscribe to Kalecki's view that innovations are capable of generating a trend" (Steindl 1979, 7). Consequently, Steindl (1964, 1976, 1979, 1981a, 1989) admits that the exhaustion of a long technological wave can contribute to the explanation of stagnation.

\section{A STEINDLIAN MODEL OF DISTRIBUTION, GROWTH, AND STAGNATION}

Steindl (1952, chapter XIII) provides a mathematical model of his theory with mixed difference-differential equations, which was meant to integrate trend and cycle theory and to explain the sources of stagnation in mature capitalism. However, in his new introduction, Steindl (1976, xvi) considers this attempt to have failed; first, because the model does not represent his theory adequately, and, second, because of the failure to rely on technological innovations or other exogenous factors to generate a long-run trend. Dutt (2005) has presented a simplified model in order to make the logic of the model more transparent. ${ }^{14}$ Here, we will simplify and slightly change Dutt's presentation even further, however, still remaining faithful to the gist of Steindl's approach. It should not come as a surprise that the result will bear close similarities with modern Kaleckian/Steindlian distribution and growth models, as can be found in the current literature. ${ }^{15}$

Let us consider a closed economy without explicitly integrating the economic activity of the state. There is just one type of commodity produced that can be used for consumption

\footnotetext{
${ }^{14}$ For more elaborated and complicated reinterpretations of Steindlian distribution and growth models, see for example Dutt (1995) and Flaschel and Skott (2006).

${ }^{15}$ See, for example, the overviews in Blecker (2002), Dutt (1990a), and Hein (2008, 2012a, 2014).
} 
and investment purposes. For a given technology or state of technological knowledge, the relationship between the employed volume of labor (L) and real output (Y) is fixed so that we get a constant labor-output ratio (a), i.e., there is no overhead-labor. The capital-potential output ratio (v), the relation between the real capital stock $(\mathrm{K})$, and potential real output $\left(\mathrm{Y}^{\mathrm{p}}\right)$, is also constant for a given technology, and the capital stock is assumed not to depreciate. When further introducing technological progress below, we will assume Harrod neutrality, that is a fall in the labor-output ratio but the constancy of the capital-potential output ratio; capital intensity and labor productivity for a given rate of capacity utilization will grow at the same rate. The rate of capacity utilization $(\mathrm{u})$ is given by the relation between actual real output and potential real output and is an endogenous variable in the model.

The goods market is dominated by oligopolies, which set prices (p) according to a mark-up (m) on unit labor costs, which are constant up to full capacity output (equation 1). The mark-up is determined by the degree of price competition in the goods market, by overhead costs, and by the bargaining power of workers and trade unions. The profit share (h), i.e., the proportion of profits ( $)$ in nominal output (pY), is therefore determined by the mark-up (equation 2). The mark-up and the profit share may become elastic with respect to overhead costs, and thus to the rentiers' rate of return on equity and bonds $(\rho)$, which is a composite of the interest rate and the dividend rate, as will be explained further below. Alternatively, a change in the outside finance-capital ratio $(\gamma)$ with a constant rentiers' rate of return may have the same effect, as will also become clear below. The profit rate (r) relates the annual flow of profits to the nominal capital stock and can be decomposed into the rate of capacity utilization, the profit share, and the inverse of the capital-potential output ratio (equation 3):

$$
\begin{aligned}
& \mathrm{p}=[1+\mathrm{m}(\rho, \gamma)] \mathrm{wa}, \quad \mathrm{m}>0, \frac{\partial \mathrm{m}}{\partial \rho} \geq 0, \frac{\partial \mathrm{m}}{\partial \gamma} \geq 0, \\
& \mathrm{~h}=\frac{\Pi}{\mathrm{pY}}=1-\frac{1}{1+\mathrm{m}(\rho, \gamma)}, \quad \frac{\partial \mathrm{h}}{\partial \rho} \geq 0, \frac{\partial \mathrm{h}}{\partial \gamma} \geq 0, \\
& \mathrm{r}=\frac{\Pi}{\mathrm{pK}} \frac{\mathrm{Y}}{\mathrm{Y}^{\mathrm{p}}} \frac{\mathrm{Y}^{\mathrm{p}}}{\mathrm{K}}=\mathrm{hu} \frac{1}{\mathrm{v}} .
\end{aligned}
$$

The pace of accumulation and growth in our model is determined by firms' decisions to invest, independently of saving, because firms have access to finance for production purposes endogenously created by the financial sector "out of nothing" at a given rate of interest. We assume that long-term finance of the capital stock consists of firms' accumulated retained 
earnings $\left(\mathrm{E}_{\mathrm{F}}\right)$, long-term credit granted by rentiers $(\mathrm{B})$, and equity issued by the firms and held by rentiers $\left(E_{R}\right)$ (equation 4$)$. Equity and debt are measured at constant issuing pricescapital gains are not considered here. The rentiers' share in capital stock, the outside financecapital ratio, is given by $\gamma$ (equation 5), whereas $\phi$ denotes the accumulated retained earnings-capital ratio or the inside finance-capital ratio (equation 6). ${ }^{16}$ Total profits (П) divide into firms' retained profits $\left(\Pi_{\mathrm{F}}\right)$ on the one hand, and dividends plus interest paid to rentiers' households $(\mathrm{R})$ on the other hand (equation 7). Interest payments to rentiers' households are given by the rate of interest and the stock of debt, and dividend payments by the dividend rate and the stock of equity held by rentiers' households. Following Steindl $(1952,217)$ and Dutt $(2005,60)$ we could assume that the interest rate and dividend rate are equal, such that the rentiers' rate of return $(\rho)$ determining rentiers income (equation 8 ) would be representing these two rates. However, although we are not interested in considering this here, we can also assume that the interest rate and dividend rate differ and the rentiers' rate of return is then the weighted average of these two rates, with the weights given by rentiers' portfolio choice:

$$
\begin{aligned}
& \mathrm{pK}=\mathrm{B}+\mathrm{E}_{\mathrm{R}}+\mathrm{E}_{\mathrm{F}}, \\
& \gamma=\frac{\mathrm{B}+\mathrm{E}_{\mathrm{R}}}{\mathrm{pK}}, \\
& \phi=\frac{\mathrm{E}_{F}}{\mathrm{pK}}, \\
& \Pi=\Pi_{F}+R, \\
& \mathrm{R}=\rho\left(\mathrm{E}_{\mathrm{R}}+\mathrm{B}\right) .
\end{aligned}
$$

When it comes to consumption and saving decisions, Steindl's (1952) model distinguishes between firms, retaining profits that are saved by definition, and households receiving incomes in terms of wages, dividends, and interests, which are partly consumed and partly saved. However, in his later work Steindl $(1979,1985,1989)$ follows Kalecki’s workercapitalist distinction rather than the firm-household classification. Here, we apply the latter distinction and distinguish between firms, workers' and capitalists'/rentiers' households. In order to simplify the analysis, we assume a classical saving hypothesis, i.e., workers do not save. The part of profits retained is completely saved by definition. The part of profits distributed to rentiers' households, the interest and dividend payments, is used by those

\footnotetext{
${ }^{16}$ This is different from the inverse of Steindl's "gearing ratio," which includes equity held by rentiers, too.
} 
households according to their propensity to save $\left(\mathrm{s}_{\mathrm{R}}\right)$. Therefore, we get the saving-capital rate $(\sigma)$ in equation (9) which relates total saving to the nominal capital stock. Note that an increase in the rentiers' rate of return, ceteris paribus, decreases the saving-capital rate because income is transferred from firms with a saving propensity of unity to rentiers' households with a saving propensity of usually less than unity:

$$
\begin{aligned}
& \sigma=\frac{\mathrm{S}}{\mathrm{pK}}=\frac{\Pi-\mathrm{R}+\mathrm{s}_{\mathrm{R}} \mathrm{R}}{\mathrm{pK}}=\mathrm{h} \frac{\mathrm{u}}{\mathrm{v}}-\left(1-\mathrm{s}_{\mathrm{R}}\right) \rho \gamma, \quad 0<\mathrm{s}_{\mathrm{R}} \leq 1 \\
& \mathrm{~g}=\frac{\mathrm{pI}}{\mathrm{pK}}=\alpha+\omega \hat{\mathrm{y}}+\beta\left(\mathrm{u}-\mathrm{u}_{0}\right)+\theta\left(\mathrm{h} \frac{\mathrm{u}}{\mathrm{v}}-\rho \gamma\right), \quad \beta, \theta, \omega>0, \quad \theta<1, \\
& \mathrm{~g}=\sigma \\
& \frac{\partial \sigma}{\partial \mathrm{u}}-\frac{\partial \mathrm{g}}{\partial \mathrm{u}}>0 \Rightarrow \quad(1-\theta) \frac{\mathrm{h}}{\mathrm{v}}-\beta>0 .
\end{aligned}
$$

The investment function (g), relating net investment (I) to the capital stock (equation 10), includes several of Steindl's arguments mentioned in the previous section. Similar to Kalecki's theories of investment (Hein 2014, chapter 5.6; Steindl 1981a), two major determinants are (expected) demand and internal means of finance. For the former, Steindl takes the deviation of the realized rate of capacity utilization from the planned rate of utilization $\left(\mathrm{u}-\mathrm{u}_{0}\right)$ as an indicator. We will return to the role of the planned rate of utilization in Steindl's model below. The latter determinant is given by retained profits, as a difference between total profits and profits distributed to rentiers in terms of interest and dividends, normalized by the capital stock, and hence by the rate of profit, the rentiers rate of return, and the outside finance-capital ratio. Of course, the argument for including internal means of finance into the investment function is provided by Kalecki's (1937) "principle of increasing risk." This means that, in imperfectly competitive financial markets, firms need own sources and capital in order to attract outside capital in terms of credit, bonds, or equity issues for investment purposes. Furthermore, under these circumstances, firms constrain their use of external capital for investment purposes in order to minimize the risk of illiquidity and insolvency. An increase in the rentiers' rate of return (i.e., of the interest rate and/or the dividend rate) or the rise in the outside finance-capital ratio each have a negative effect on capital accumulation. We have included a constant $(\alpha)$ into the investment function, which may be taken to capture autonomous investment expenditures, as well as "animal spirits" of firms or management driving the investment decisions. In a more extended model, $\alpha$ may 
also be taken to represent autonomous and deficit-financed government expenditure growth. Finally, we can include the effects of technological progress and innovations on capital accumulation, which Steindl (1952) had ignored in his model but conceded in his later work, and highlighted in Steindl (1981b). Therefore, we have added a positive effect of innovation and (potential) labor productivity growth $(\hat{y})$, because technological progress is (at least partially) capital embodied. Let us also assume that technological progress is Harrod-neutral and that hence the capital-potential output ratio remains constant. Equation (11) provides the equilibrium condition, i.e., the equality of saving and investment decisions, and (12) the usual Keynesian/Kaleckian stability condition, which requires the saving rate to respond more vigorously to a change in the rate of capacity utilization than the rate of capital accumulation.

The equilibrium rates of capacity utilization, capital accumulation, and profit are as follows:

$$
\begin{aligned}
& u^{*}=\frac{\alpha+\omega \hat{y}-\beta u_{0}+\rho \gamma\left(1-s_{R}-\theta\right)}{(1-\theta) \frac{h}{v}-\beta}, \\
& g^{*}=\frac{\left(\alpha+\omega \hat{y}-\beta u_{0}\right) \frac{h}{v}+\rho \gamma\left[\beta\left(1-s_{R}\right)-\theta s_{R} \frac{h}{v}\right]}{(1-\theta) \frac{h}{v}-\beta}, \\
& r^{*}=\frac{\left[\alpha+\omega \hat{y}-\beta u_{0}+\rho \gamma\left(1-s_{R}-\theta\right)\right] \frac{h}{v}}{(1-\theta) \frac{h}{v}-\beta} .
\end{aligned}
$$

In this paper we will not touch upon the endogenous dynamics of the outside finance-capital ratio and its stability properties, the potential for "paradoxes of debt" or "paradoxes of outside finance," and so on. The interested reader is referred to the discussion based on similar models, like, for example, in Dutt (1995), Hein (2010; 2012a, chapter 3; 2013), Sasaki and Fujita (2012), and Franke (2015). We shall also not deal extensively with the question of whether an equilibrium rate of utilization $\left(\mathrm{u}^{*}\right)$ deviating from firms' target rate of utilization $\left(\mathrm{u}_{0}\right)$ should be considered as an equilibrium. Steindl (1952, 12; emphasis in the original) is quite explicit on that issue, when he argues that " $[\mathrm{t}]$ he degree of utilisation actually obtaining in the long run, we must conclude, is no safe indication of the planned level of utilisation." Marxian and Harrodian authors, like Dumenil and Levy (1999), Shaikh (2009), and Skott (2010, 2012), however, have argued that such a position should not be considered to be a long-run equilibrium, but would rather trigger responses by firms. Thus "Harrodian 
instability" would arise, which would then have to be contained by other mechanisms in the model (changes in distribution or animal spirits, or government and central bank interventions). As has been reviewed by Hein, Lavoie, and van Treeck $(2011,2012)$, Kaleckian and Steindlian authors have put forward different justifications for taking the rate of capacity utilization as an adjusting and endogenous variable, probably within bounds, nonetheless: Normal or target rates of utilization cannot be precisely determined in a world of fundamental uncertainty about future events and should thus rather be considered as a range (Dutt 1990b, 2005, 2010). Firms may have multiple goals and accept variations in capacity utilization and hence deviations from the target or normal rate in the long-run equilibrium to come closer to meeting other targets, for instance dividend payments demanded by shareholders (Dallery and van Treeck 2011). Firms' assessment of trend growth and the normal rate of utilization may endogenously adjust to actual experience (Lavoie 1995a, 1996). And finally, the target or normal rate as a stable inflation rate of utilization may itself be endogenous to inflation targeting monetary policies when the interest cost and distribution channels of interest rate policies are considered (Hein 2006; 2008, chapter 17).

From equations (13)-(15) the effects of changes in $\alpha, \omega \hat{y}, s_{R}$, and $u_{0}$ on the equilibrium rates of capacity utilization, capital accumulation, and profit can easily be identified. A fall in animal spirits or in the growth of autonomous investment, also of the growth of autonomous consumption, government deficit spending, or exports in more elaborated models, have negative effects on economic activity, growth, and the rate of profit. A lower rate of technological progress and innovations, indicated by (potential) labor productivity growth, or a lower responsiveness of investment towards technological progress have contractive effects on all equilibrium values as well. The same is true for a higher propensity to save out of rentiers' income. This means the paradox of thrift is also valid for Steindl's approach. Additionally, a higher target rate of utilization of firms has depressive effects on capacity utilization, capital accumulation, and the profit rate. For the effects of changes in the profit share and hence in functional income distribution we get the following results: 
(13a) $\frac{\partial \mathrm{u}^{*}}{\partial \mathrm{h}}=\frac{-(1-\theta) \frac{\mathrm{u}}{\mathrm{v}}}{(1-\theta) \frac{\mathrm{h}}{\mathrm{v}}-\beta}<0$,

(14a) $\frac{\partial \mathrm{g}^{*}}{\partial \mathrm{h}}=\frac{-\beta \frac{\mathrm{u}}{\mathrm{v}}}{(1-\theta) \frac{\mathrm{h}}{\mathrm{v}}-\beta}<0$,

(15a) $\frac{\partial \mathrm{r}^{*}}{\partial \mathrm{h}}=\frac{-\beta \frac{\mathrm{u}}{\mathrm{v}}}{(1-\theta) \frac{\mathrm{h}}{\mathrm{v}}-\beta}<0$.

A rise in the profit share thus has negative effects on the equilibrium rates of capacity utilization, capital accumulation, and profit. Demand and growth in the Steindlian model are wage-led, and for the rate of profit we have the "paradox of costs," i.e., a higher wage share and thus higher real unit labor costs trigger a higher profit rate. We will finally take a look at the effects of changes in our financial variables, the rentiers' rate of return and the outside finance-capital ratio:

$$
\frac{\partial \mathrm{u}^{*}}{\partial \rho}=\frac{\gamma\left(1-\mathrm{s}_{\mathrm{R}}-\theta\right)-(1-\theta) \frac{\mathrm{u}}{\mathrm{v}} \frac{\partial \mathrm{h}}{\partial \rho}}{(1-\theta) \frac{\mathrm{h}}{\mathrm{v}}-\beta}
$$

$$
\frac{\partial u^{*}}{\partial \gamma}=\frac{\rho\left(1-s_{R}-\theta\right)-(1-\theta) \frac{\mathrm{u}}{v} \frac{\partial \mathrm{h}}{\partial \gamma}}{(1-\theta) \frac{\mathrm{h}}{\mathrm{v}}-\beta}
$$

$$
\frac{\partial \mathrm{g}^{*}}{\partial \rho}=\frac{\gamma\left[\beta\left(1-\mathrm{s}_{\mathrm{R}}\right)-\theta \mathrm{s}_{\mathrm{R}} \frac{\mathrm{h}}{\mathrm{v}}\right]-\beta \frac{\mathrm{u}}{\mathrm{v}} \frac{\partial \mathrm{h}}{\partial \rho}}{(1-\theta) \frac{\mathrm{h}}{\mathrm{v}}-\beta}
$$

(14c) $\frac{\partial \mathrm{g}^{*}}{\partial \gamma}=\frac{\rho\left[\beta\left(1-\mathrm{s}_{\mathrm{R}}\right)-\theta \mathrm{s}_{\mathrm{R}} \frac{\mathrm{h}}{\mathrm{v}}\right]-\beta \frac{\mathrm{u}}{\mathrm{v}} \frac{\partial \mathrm{h}}{\partial \gamma}}{(1-\theta) \frac{\mathrm{h}}{\mathrm{v}}-\beta}$,

$$
\frac{\partial \mathrm{r}^{*}}{\partial \rho}=\frac{\gamma\left(1-\mathrm{s}_{\mathrm{R}}-\theta\right) \frac{\mathrm{h}}{\mathrm{v}}-\beta \frac{\mathrm{u}}{\mathrm{v}} \frac{\partial \mathrm{h}}{\partial \rho}}{(1-\theta) \frac{\mathrm{h}}{\mathrm{v}}-\beta}
$$




$$
\frac{\partial \mathrm{r}^{*}}{\partial \gamma}=\frac{\rho\left(1-\mathrm{s}_{\mathrm{R}}-\theta\right) \frac{\mathrm{h}}{\mathrm{v}}-\beta \frac{\mathrm{u}}{\mathrm{v}} \frac{\partial \mathrm{h}}{\partial \gamma}}{(1-\theta) \frac{\mathrm{h}}{\mathrm{v}}-\beta}
$$

Let us first discuss the case of interest- and dividend payments-inelastic mark-ups, and profit shares. In this case, a rise in the rentiers' rate of return, hence in the interest rate and/or the dividend rate, or an increase in the outside finance-capital ratio, will redistribute income from firms that do not consume to rentiers who consume at least a part of the income. This will boost consumption demand and, through the accelerator in the investment function, also investment demand and hence capital accumulation. However, the drain of internal means of finance of firms will have a partially negative effect on capital accumulation. The overall or equilibrium effect will thus depend on the relative strengths of each of these partial effects.

Table 1 summarizes the potential cases.

\begin{tabular}{|c|c|c|c|}
\hline & $\begin{array}{l}\text { "normal case" } \\
\text { "debt-burdened" } \\
\text { economy }\end{array}$ & "intermediate case" & $\begin{array}{l}\text { "puzzling case" } \\
\text { "debt-led" economy }\end{array}$ \\
\hline & $1-\mathrm{s}_{\mathrm{R}}<\theta$ & $\theta<1-\mathrm{s}_{\mathrm{R}}<\theta \frac{\frac{\mathrm{h}}{\mathrm{v}}}{\beta+\theta \frac{\mathrm{h}}{\mathrm{v}}}$ & $\theta \frac{\frac{\mathrm{h}}{\mathrm{v}}}{\beta+\theta \frac{\mathrm{h}}{\mathrm{v}}}<1-\mathrm{s}_{\mathrm{R}}$ \\
\hline$\frac{\partial u}{\partial \rho}, \frac{\partial u}{\partial \gamma}$ & - & + & + \\
\hline$\frac{\partial g}{\partial \rho}, \frac{\partial g}{\partial \gamma}$ & - & - & + \\
\hline$\frac{\partial \mathrm{r}}{\partial \rho}, \frac{\partial \mathrm{r}}{\partial \gamma}$ & - & + & + \\
\hline \multicolumn{4}{|c|}{$\begin{array}{l}\text { Note: Assuming the stability condition (12) for the goods market equilibrium to hold implies } \\
(\mathrm{h} / \mathrm{v}) /[\beta+\theta(\mathrm{h} / \mathrm{v})]>1 \text {, because from }(1-\theta)(\mathrm{h} / \mathrm{v})-\beta>0 \text {, we get }(\mathrm{h} / \mathrm{v})-\theta(\mathrm{h} / \mathrm{v})>\beta \text {, and hence } \\
(\mathrm{h} / \mathrm{v})>\beta+\theta(\mathrm{h} / \mathrm{v}) \text {. }\end{array}$} \\
\hline
\end{tabular}

If the rentiers' propensity to consume $\left(1-s_{R}\right)$ falls short of firms' investment responsiveness towards internal funds $(\theta)$, we are in the "normal case" (Lavoie 1995b), and an increase in the rentiers' rate of return and/or in the outside finance-capital economy will trigger lower equilibrium rates of capacity utilization, capital accumulation, and profit. In this case, the 
economy will also be "debt-burdened" (Taylor 2008, 275), because a higher debt-capital ratio will cause lower rates of capacity utilization, capital accumulation, and profit. If the rentiers' propensity to consume exceeds the firms' investment responsiveness towards internal funds, but the effects of capacity utilization on firms' investment $(\beta)$ is low, we are in the “intermediate case," with positive effects of higher rentiers' rates of return and/or outside finance-capital ratios on capacity utilization and the rate of profit, but negative effects on capital accumulation. Finally, if the conditions for the intermediate case hold and the effect of capacity utilization on investment is high, we may even obtain the "puzzling case" (Lavoie 1995b), in which a higher rentiers' rate of return and/or a higher outside finance-capital ratio have expansionary effects on the rates of capacity utilization, capital accumulation, and profit. In this case, the economy is also uniquely "debt-led" (Taylor 2008, 275); a higher debt-capital ratio will cause higher rates of capacity utilization, capital accumulation, and profit.

Table 2 presents the properties of our simplified Steindlian distribution and growth model and summarizes the responses of the equilibrium rates of capacity utilization, capital accumulation, and profit towards changes in the exogenous variables and parameters. Our Steindlian model economy would enter into periods of low capacity utilization, low growth, and also a low profit rate, and hence into a period of stagnation, under the following conditions:

- a fall in autonomous investment growth (or autonomous consumption, government expenditures, or exports) and/or a fall in "animal spirits" of firms;

- a fall in the rate of productivity-enhancing innovations driving investment;

- a rise in the target rate of capacity utilization of firms;

- a rise in the rentiers' propensity to save (or in the workers' propensity to save set equal to zero in the current model version);

- $\quad$ a rise in the profit share;

- a rise in the rentiers' rate of return, hence the interest rate and/or the dividend rate, and/or the outside finance-capital ratio, hence the debt- and/or the rentiers' equitycapital ratio, if the economy is in the "normal case" and in a "debt-burdened" regime, or a fall in the rentiers' rate of return and/or the outside finance-capital ratio if the economy is in the "puzzling case" and in a "debt-led regime." 


\begin{tabular}{|l|l|l|l|}
\hline \multicolumn{5}{|l|}{ Table 2: Responses of equilibrium rates of capacity utilization (u), capital } \\
accumulation (g), profit (r) towards changes in exogenous variables and \\
parameters & u* & g* & r* \\
\hline$\alpha$ & + & + & + \\
\hline$\omega \hat{y}$ & + & + & + \\
\hline$u_{0}$ & - & - & - \\
\hline$S_{R}$ & - & - & - \\
\hline$h$ & - & - & - \\
\hline$\rho$ & $?$ & $?$ & $?$ \\
\hline$\gamma$ & $?$ & $?$ & $?$ \\
\hline
\end{tabular}

So far, we have only discussed the demand side of the Steindlian distribution and growth model and have introduced innovations and technological change as an exogenous variable driving investment and growth. However, starting with Rowthorn (1981), Dutt (1990a, chapter 5), Taylor (1991, chapter 10), and Lavoie (1992, chapter 6), post-Keynesian authors have introduced endogenous technological change and labor productivity growth into Steindlian/Kaleckian distribution and growth models, as reviewed and elaborated on in Hein 2014 , chapter 8). Relying on Kaldor's $(1957,1961)$ technical progress function and/or on Kaldor's (1966) Verdoorn's Law, labor productivity growth is assumed to be positively affected by capital stock growth, due to capital-embodied technological change, and/or demand growth and hence the rate of capacity utilization, due to dynamic returns to scale. And following Marx (1867) and Hicks (1932), several authors have integrated a wage-push variable into the productivity growth function of the model, arguing that a higher real wage rate or a higher wage share induces capitalists to speed up the implementation of labor augmenting technological progress in order to protect the profit share. If we add a summary variable $(\eta)$ representing the effect of "learning by doing" and/or basic innovations, we get the following function for labor productivity growth:

$$
\hat{y}=\eta+\varepsilon g-\psi h, \quad \eta, \varepsilon, \psi>0 .
$$

As can be seen in figure 1, which shows the long-run endogenous growth equilibrium generated by equations (14) and (16), any fall in the goods market equilibrium rate of capital accumulation, that is a leftwards shift in the $\mathrm{g}^{*}$ function, will also cause a lower long-run equilibrium rate of productivity growth and hence of potential growth. The economy will 
move from the equilibrium in point $\mathrm{A}$ to the one in point B. And if the fall in capital accumulation is caused by a higher profit share, the directly negative impact on productivity growth has to be included as well, and the economy will move to the long-run equilibrium in point $\mathrm{C}$ with even lower capital stock, output, and productivity growth. Of course, further effects could be discussed here, as, for example, a change in the nature of technical progress, as a decline in the capital-potential output ratio. If the implementation of technical progress required less investment in the capital stock, the coefficient $\omega$ in the investment function (equation 10) would be lowered, the $g *$ function in figure 1 would rotate counter-clockwise, and the long-run equilibrium growth rates of capital stock, output, and productivity would fall even below point $\mathrm{C}$ (Hein 2012b).

\section{Figure 1: Stagnation with endogenous productivity growth}

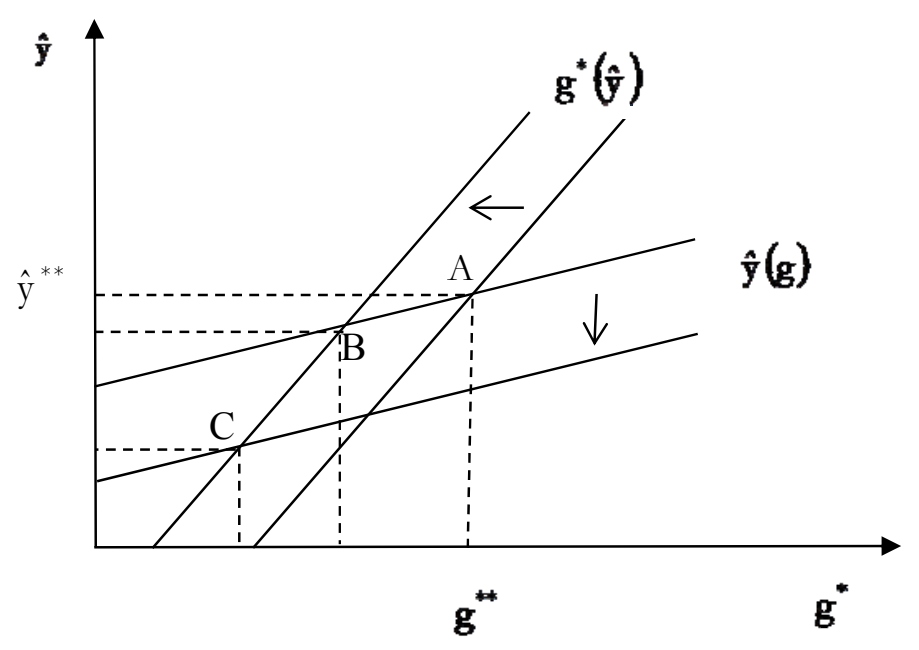

\section{THE ROLE OF INSTITUTIONS AND POLICIES-OR WHY STAGNATION DID NOT MATERIALIZE IN THE 1950S AND 1960S BUT HAS BECOME MORE LIKELY SINCE THE 1980S—AND AFTER THE GREAT RECESSION IN PARTICULAR $^{17}$}

Let us next follow Steindl's $(1976,1979,1989)$ explanations, on why his postulated tendencies towards stagnation did not materialize in the golden age period of mature capitalism from the 1950s until the mid-1970s. In Steindl (1979) we find four reasons for high growth in the post-World War II period, reversing the inherent stagnation tendencies. In terms of the model of the previous section, stagnation tendencies were mainly reversed through those factors causing a rise in $\alpha$ and $\omega \hat{y}$ or a fall in $h$ :

\footnotetext{
${ }^{17}$ This section partly draws on Hein $(2014,227-234)$.
} 
- Public spending increased tremendously after World War II, financed to a great extent by taxes on profits. This increased capacity utilization and fed back positively on firms' decisions to invest in capital stock.

- Technological competition between East and West, the "competition of the systems," had a strong impact on expenditures on R\&D and education by the governments, which spilled over to the private sector, boosting investment and productivity growth.

- The postwar tensions triggered close cooperation of the Western countries under the leadership of the US. This included the world financial system of Bretton Woods with fixed but adjustable exchange rates, the Marshall Plan, and American lending to Western European countries, which stabilized and provided the conditions for an increase in international trade. A higher level of international trade kept profit margins within limits and contributed to stabilizing wage shares.

- European countries benefited from technological backwardness with respect to the US and could make use of technological knowledge, which had been generated and applied in the US, thus making use of the "catching-up" factor in economic growth.

In other publications, Steindl also adds factors operating through lowering the propensity to save of households and through improved internal finance conditions of firms, obviously assuming the "normal" and "debt-burdened" case conditions to prevail. For example, Steindl (1976) mentions as a further growth-enhancing factor that big corporations spread their activities to several industries reducing impediments to the flow of funds between industries, which favored aggregate investment. In addition, the shortening of construction periods and the introduction of consumer credit on a larger scale were favorable for growth. Steindl (1989) also adds the low indebtedness of corporations right after World War II as a factor that was favorable to investment in capital stock and to GDP growth, as well as the increasing bargaining power of workers and trade unions associated with full employment, which held mark-ups and profit shares in check and allowed real wages to grow in step with productivity thus providing the required demand growth.

The faltering of the post-World War II golden age and the reemergence of stagnation tendencies starting in the mid-1970s are analyzed in detail by Steindl (1979). Here, several causes are related to the factors determining $\alpha$ and $\omega \hat{y}$ in our model: 
- The reduction of tensions between the superpowers, an increase in internal rivalries among the capitalist economies, a decay of US leadership, and the collapse of the Bretton Woods international financial system indicated an absence of the willingness and the ability for international cooperation leading to rising uncertainty.

- The fading out of the catching-up potential of Europe towards the US associated with abnormally high rates of productivity growth in Europe over the postwar period lowered the incentives to invest.

- Increasing environmental and energy problems increased energy prices putting upwards pressure on inflation rates and raised uncertainty with respect to future technological development.

Further factors contributing to the reemergence of stagnation, according to Steindl (1979), are related to the effects of demand and capacity utilization on investment and to the propensity to save of households:

- Supposed tendencies towards increasing capital productivity reduced the required amounts of net investment to increase productive capacities, thus lowering $\beta$ in our model.

- And a trend towards an increasing marginal propensity to save from disposable household income in prospering economies weakened aggregate demand, capacity utilization, investment, and growth.

However, the most important factor that explains the reemergence of stagnation tendencies, according to Steindl (1979), is "stagnation policy" in the major capitalist economies, which he had already briefly mentioned three years earlier: "[...] thus we witness stagnation not as an incomprehensible fate, as in the 1930s, but stagnation as policy" (Steindl 1976, xvii). In this context, Steindl (1979) refers to Kalecki's (1971, chapter 12) Political Aspects of Full Employment, in which Kalecki argues that, although governments might know how to maintain full employment in a capitalist economy, they will not do so, because of capitalists' opposition. Kalecki (1971, 139; emphasis in the original) presents the following reasons: 
The reasons for the opposition of the "industrial leaders" to full employment achieved by Government spending may be subdivided into three categories: (i) the dislike of Government interference in the problem of employment as such; (ii) the dislike of the direction of Government spending (public investment and subsidizing consumption); (iii) dislike of the social and political changes resulting from the maintenance of full employment.

Whereas in Kalecki $(1971,144)$, the opposition of the capitalist class towards full employment policies gave rise to a "political business cycle," Steindl $(1979,9)$ argues that business opposition towards full employment policies generates a "political trend" causing or contributing to stagnation. In the course of the 1970s, governments, facing full employment and increasing rates of inflation, moved away from targeting full employment by means of active demand management towards targeting price stability by means of restrictive monetary policies and containing public deficits and debt. In terms of our model in the previous section, the major channels through which stagnation policies depress the economy are:

- decreasing $\alpha$ (decrease in autonomous expenditure growth, falling animal spirits);

- falling $\omega \hat{y}$ (lower growth enhancing public investment, lower investment in R\&D);

- raising the profit share h (weakening workers' and trade union bargaining power, higher interest, and hence overhead costs);

- a rise in the households' propensity to save (rising inequality in the distribution of household incomes, higher uncertainty triggering precautionary saving);

- and through rising real rates of interest, rentiers' rates of return $(\rho)$, and real debtcapital and outside-finance capital ratios $(\gamma)$ of firms, with "normal cases" and "debtburdened" constellations prevailing.

In his latest contributions, Steindl relates stagnation tendencies and stagnation policy to an increasing dominance of the financial sector in modern capitalist economies. In Bhaduri and Steindl (1985), stagnation policies are associated with "the rise of monetarism as a social doctrine," because monetarism is inherently linked with restrictive fiscal and monetary policies, which are supported by banks and the financial sector (or the rentiers). The application of monetarist policies thus indicates a shift of powers from industry to banks, or from the non-financial sector of the economy to the financial sector, which occurred in the course of national and international financial liberalization and rapidly increasing financial activity in the 1970s and early 1980s (collapse of the Bretton Woods international financial 
system, rise of the Eurodollar market, emergence of oil exporting countries as a class or “international rentiers," emergence of international commercial banks). In Steindl (1989), it is stressed that, starting in the $1980 \mathrm{~s}$, the tendencies towards weak investment and stagnation have then been amplified by a shift of the interest of corporations and their managers from production towards finance and an increasing role of financial investment in comparison to real investment.

The increasing dominance of finance, or "financialization," starting in the early 1980s in the US and the UK and somewhat later in other countries, has been analyzed extensively applying Kaleckian/Steindlian distribution and growth models. Reviews of models and empirical applications can be found in Hein (2012a; 2014, chapter 10), Hein and Dodig (2015), and Hein and van Treeck (2010). The major findings have been that, on the one hand, confirming Steindl's latest hypotheses, the increasing dominance of finance has depressed the economy. The major channels have been, first, the redistribution of income at the expense of the labor income share and the low-income households, which have depressed incomefinanced consumption demand. Second, the increasing dominance of finance and rising shareholder value orientation of management has depressed investment in the capital stock, mainly through the "animal spirit channel" and through the "internal means of finance channel" of our model in the previous section. Management of non-financial corporations increasingly favored short-run profit maximization by means of financial investment instead of real investment in the capital stock of the firm generating profits in the long run. And increasing dividend payments and share-buybacks have eroded internal means of finance, partly even increasing the indebtedness of non-financial business, and thus further depressing investment in the capital stock.

However, on the other hand, going beyond Steindl's contributions, it has been argued that the expansion and development of the financial sector and the increasing dominance of finance have also stimulated the economy in the short and medium run. First, regarding consumption, financialization has generated an increasing potential for wealth-based and debt-financed consumption. In several countries, stock market and housing price booms have each increased notional wealth against which households were willing to borrow. Changing financial norms, new financial instruments (credit card debt, home equity lending), deterioration of creditworthiness standards (triggered by securitization of mortgage debt, credit card debt, etc.), and "originate and distribute" strategies of commercial banks made increasing credit available to low-income, low-wealth households, in particular. This potentially allowed for consumption to rise faster than median income, thus stabilizing 
aggregate demand and growth. But, it also generated increasing debt-income ratios of private households. Second, the liberalization of international capital markets and capital accounts has allowed several countries to run persistent and rising current account deficits, and a corresponding set of countries to have their demand and growth driven by rising net exports generating increasing current account surpluses. Therefore, rising current account imbalances at the global, but also at the regional levels, in particular within the Euro area, have been generated, as well as increasing problems of foreign indebtedness, speculative capital movements, exchange rate volatilities, and related potentials for currency crises.

Therefore, against the background of finance-dominated capitalism, two extreme but complementary growth regimes have developed, as has been analyzed using different terminologies by Hein (2012a, chapter 6; 2014, chapter 10), Hein and Dodig (2015), Hein and Mundt (2012), Horn, Joebges, and Zwiener (2009), Stockhammer (2010, 2012, 2015), UNCTAD (2009), and van Treeck and Sturn (2012), among others. The "debt-led consumption boom" regimes, as in the US, the UK, Spain, and other countries, relied on credit-financed private demand, and private consumption in particular, as the main drivers of demand and growth, accepting increasing current account deficits. The "export-led mercantilist" regimes, as in Germany, China, Japan, and other smaller and more open economies, saw their demand and growth being driven by rising net exports generating rising current account surpluses.

Each regime can be conceived of as a "profits without investment" regime, because dynamic capital stock growth is either substituted by credit-financed consumption demand or net export growth. Since productivity growth, and thus "natural" or potential growth, are to a large extent embodied in capital stock growth and also driven by real wage growth (as briefly explained above in our Steindlian model) dampened investment in capital stock and stagnant real wage growth each contributed to low labor productivity growth and thus lower potential growth in finance-dominated capitalism (Hein 2012a, chapter 4; 2012b). Furthermore, the "debt-led consumption" regime and the "export-led mercantilist" regime have suffered from further internal contradictions, with respect to household debt in the first regime and with respect to foreign debt of the corresponding current account deficit countries in the second regime. These finally undermined the sustainability of these regimes and the related current account imbalances, and led to the financial and economic crisis of 2007-09. As is well known, this crisis was triggered by over-indebtedness problems of private households in the leading "debt-led consumption boom" economy, the US. This crisis quickly spread to the “export-led mercantilist economies." First, their export markets collapsed (foreign trade 
channel). Second, their capital exports into risky and now collapsing financial markets in the current account deficit countries, associated with persistent current account surpluses, were devalued (financial contagion channel). Furthermore, an uncertainty and expectations channel took effect as well. The crisis did neither lead to a collapse of the world economy nor to a prolonged depression at the global level, due to appropriate fiscal and monetary stabilization policies for the financial and non-financial sectors of the economy. However, more than seven years after the beginning of the crisis, the impression is that the world economy as a whole is facing slower growth, and stagnation has become the rule of the game again in certain regions, in particular in those that have turned towards stagnation policy again, as the Euro area.

From the Steindlian perspective we can thus conclude that the main constraint a capitalist economy is facing in the long run is sustainable demand generation. Stagnation is thus mainly caused by those factors slowing down sustainable demand growth-i.e., demand growth that is not driven by ever-rising debt-income ratios of any macroeconomic sector. Any lack of sustainable demand growth will feedback negatively on potential or "natural" growth. Reversing stagnation policy is thus the main objective when it comes to fighting stagnation tendencies in mature, finance-dominated capitalist economies.

\section{ECONOMIC POLICY IMPLICATIONS}

Here is not the place to spell out in any detail the economic policy implications of the Steindlian approach towards stagnation presented in the previous sections. We will just touch upon the broad lines of Steindlian anti-stagnation policies and refer to more detailed recent contributions of Steindlian/Kaleckian/post-Keynesian authors. From Steindl's analysis of stagnation policy and the increasing dominance of finance capital as major causes for stagnation tendencies, it follows that anti-stagnation policies would have to focus on the following areas: ${ }^{18}$

- stabilizing and raising public autonomous expenditure growth, as well as discretionary anticyclical fiscal policies, in order to stabilize effective demand growth, prevent deflation with its negative effects on private demand, and to improve the general climate for private sector investment and consumption;

\footnotetext{
${ }^{18}$ See also Guger, Marterbauer, and Walterskirchen (2006) for an excellent review of Steindlian economic policy implications in general, as well as an outline of Steindlian policy alternatives for the EU in order to boost aggregate demand, employment, and growth, instead of continuing with stagnation policies.
} 
- raising growth enhancing public investment, focusing on infrastructure, technology, education, and $R \& D$ expenditures, in order to stimulate private investment and $R \& D$ outlays;

- stabilizing and raising the wage share by full employment policies improving workers' bargaining power, by low interest rate policies reducing overhead costs, and by the re-regulation of the financial sector reducing the power and income claims of rentiers and shareholders;

- lowering the households' propensity to save by means of redistributing income, both pre-tax via higher wage shares and a more compressed wage structure and after-tax by progressive taxation and social transfers, as well as by removing uncertainty triggering precautionary saving;

- improving international economic and monetary policy coordination in order to avoid severe current account imbalances, "beggar-thy-neighbor" strategies on the one hand, and rising indebtedness in foreign currencies on the other hand.

Several of these Steindlian elements can be found in economic policy proposals based on the analysis of the contradictions immanent to finance-dominated capitalism and the recent financial and economic crises outlined in the previous section. Since the two extreme types of development under financialization, the "debt-led consumption boom" type and the "exportled mercantilist" type, have proven to be unsustainable, ILO (2012), Lavoie and Stockhammer (2013a, 2013b), and Stockhammer and Onaran (2012, 2013), among others, have argued that a sustainable recovery strategy after the crises can only focus on a "wageled" or "mass income-led" type of development and hence on the redistribution of income from profits to wages and from the top to the bottom. Hein $(2011 ; 2012 \mathrm{a}$, chapter 7), Hein and Mundt (2012), and Hein and Truger (2011, 2012/13) have argued that the focus of such a strategy is too narrow, because, on the one hand, the potential for redistribution given the current power relationships is overestimated, as are the potential demand and growth effects of such redistributions, if they are feasible at all in isolation. Therefore, they have suggested that a wage-led recovery strategy would have to be embedded in a Global Keynesian New Deal, which more broadly should address the main characteristics of finance-dominated capitalism and the main causes for the severity of the crisis: the inefficient regulation of financial markets, the increasing inequality in the distribution of income, and the rising imbalances at the global (and at regional) level. The three main pillars of the policy package of a Global Keynesian New Deal are the following: First, it includes the re-regulation of the 
financial sector in order to increase transparency, to raise incentives to focus on long-term growth instead of short-term profit, and to prevent or contain future financial excesses and financial crises. Second, it focuses on the reorientation of macroeconomic policies towards stimulating and stabilizing domestic demand, in particular in current account surplus countries. This includes monetary policies targeting low long-term interest rates, fiscal policies stabilizing aggregate demand at non-inflationary full employment levels in the short and in the long run applying a "functional finance" approach, and wage or incomes policies stabilizing income distribution and inflation at some target rate. And third, it has to include the reconstruction of international macroeconomic and monetary policy coordination and a new world financial order in order to prevent export-led mercantilist and hence "beggar-thyneighbor" strategies. Palley (2012, chapter 9; 2013, chapter 12) and UNCTAD (2009), among others, have made similar suggestions. The roles of technology and innovation policies, which have been of utmost importance for Steindl, have not been explicitly addressed in the approaches mentioned so far. However, Mazzucato (2013) and Mazzucato and Penna (2015) have recently stressed the role of the government and of state investment bank finance for innovation and technology development. These contributions nicely complement the more general suggestions mentioned above.

Finally, comparing the policy recommendations of the Steindlian approach with the economic policy implications of the current debate on secular stagnation reveals the following. First, the Steindlian policy stance contradicts those approaches, which exclusively focus on promoting potential growth through supply-side measures. The Steindlian approach does not ignore the supply side; on the contrary, it carefully takes into account supply- and demand-side determinants of growth, but it acknowledges the endogeneity of many of the supply-side determinants of potential growth. Second, the Steindlian approach encompasses those policy suggestions aimed at lifting actual output growth towards a presumably given potential growth rate through low interest rate policies, expansionary fiscal policies, and the stimulation of private investment and consumption. However, the Steindlian view takes into account the required changes in power relationships, institutions, and distribution of wealth and income, both nationally and internationally, as well as the feedback effects on potential growth. The policy implications are thus much broader and richer. 


\section{CONCLUSIONS}

In this paper we have briefly reviewed the current debate on "secular stagnation" and we have found this debate to be deficient in terms of the theoretical foundations and the economic policy implications. First, at the very foundations, even of the presumably more Keynesian works, we have an equilibrium real or natural rate of interest, in principle equalizing saving and investment in the capital market at full employment output levels, which, however, may not be feasible because of a very low or even negative equilibrium rate. This approach is open to critique from the "Cambridge controversies in the theory of capital," questioning an interest rate inverse and continuously downward sloping capital demand curve in a more-than-one-good economy, as well as the Keynesian critique with respect to the causalities between and adjustments of saving and investment in a monetary production economy. Second, most of the current literature on secular stagnation seems to assume that the natural or potential rate of growth is more or less independent of aggregate demand dynamics, thus ignoring potential feedback and endogeneity channels. And third, in the modern discussion on secular stagnation changes in institutions and power relationships between social classes, as related to the rise of finance-dominated capitalism over the last three decades or so, do not seem to have an important role to play at all. Therefore, the policy recommendations on how to deal with secular stagnation proposed in the recent literature can be considered to be either misguided or at least incomplete.

For these reasons, we have provided an alternative view on stagnation tendencies based on Josef Steindl's contributions. We have argued that this work is not prone to the problems detected in the current debate on secular stagnation: It does not rely on the dubious notion of an equilibrium real interest rate as the equilibrating force of saving and investment at full employments levels, in principle, with the adjustment process currently blocked by the unfeasibility of a very low or even negative equilibrium rate. It is based on the notion that modern capitalist economies are facing aggregate demand constraints in the long run, and that saving adjusts to investment through income growth and changes in capacity utilization in the long run. Also, it allows for potential growth to become endogenous to actual demand-driven growth. Finally, it seriously considers the role of institutions and power relationships for long-run growth - and for stagnation.

We have developed a simple Steindlian model of distribution and growth in order to identify the potential causes of stagnation, namely low capacity utilization, low capital stock growth, low productivity growth, and a low rate of profit. This model has then been used to 
outline Steindl's view on the golden age period of modern capitalism in the 1950s and 1960s, the reappearance of stagnation tendencies in the 1970s, and their reinforcements by stagnation policy and the increasing dominance of finance capital since the 1980s. We have considered further developments of the Steindlian concept by Kaleckian/Steindlian/postKeynesian authors in order to apply it to the contradictions of finance-dominated capitalism and the recent financial and economic crises. Finally we have drawn some broad economic policy conclusions in order to tackle the current tendencies of stagnation. These include the reregulation of the financial sector in order to decrease the power of finance, the reorientation of macroeconomic policies towards the stabilization of domestic demand and employment, a strong focus of government policies on fostering technology, education, and R\&D, and the coordination of international economic and monetary policies. 


\section{References}

Backhouse, R.E., Boianovsky, M. (2015): Secular stagnation: the history of a macroeconomic heresy, version 1, preliminary draft of paper prepared for the Blanqui Lecture (Meetings of the European Society for the History of Economic Thought, Rome, 14 May 2015).

Baran, P.A., Sweezy, P.M. (1966): Monopoly Capital, New York: Monthly Review Press.

Bhaduri, A., Steindl, J. (1985): The rise of monetarism as a social doctrine, in: Arestis, P., Skouras, T. (eds.), Post-Keynesian Economic Theory, Sussex: Wheatsheaf.

Blanchard, O., Dell'Ariccia, G., Mauro, P. (2010): Rethinking macroeconomic policy, IMF Staff Position Note SPN/10/03.

Blanchard, O., Furceri, D., Pescatori, A. (2014): A prolonged period of low real interest rates?, in: Teulings, C., Baldwin, R. (eds.), Secular Stagnation: Facts, Causes and Cures. A VoxEU.org eBook, London: Centre for Economic Policy Research (CEPR).

Bleany, M. (1976): Underconsumption Theories. History and Critical Analysis, New York: International Publishers.

Blecker, R.A. (2002): Distribution, demand and growth in neo-Kaleckian macro-models, in: Setterfield, M. (ed.), The Economics of Demand-Led Growth, Cheltenham: Edward Elgar.

Cowling, K. (1982): Monopoly Capitalism, London: Macmillan.

Crafts, N. (2014): Secular stagnation, US hypochondria, European disease?, in: Teulings, C.,

Dallery, T., van Treeck, T. (2011): Conflicting claims and equilibrium adjustment processes in a stock-flow consistent macro model, Review of Political Economy, 23: 189-211.

Duménil, G., Lévy, D. (1999): Being Keynesian in the short term and classical in the long term: the traverse to classical long-term equilibrium, The Manchester School, 67: 684716 .

Dutt, A.K. (1990a): Growth, Distribution and Uneven Development, Cambridge, UK: Cambridge University Press.

Dutt, A.K. (1990b): Growth, distribution and capital ownership: Kalecki and Pasinetti revisited, in: Dutta, B., Gangopadhyay, S., Mookherjee, D., Ray, D. (eds.), Economic Theory and Policy. Essays in honour of Dipak Banerjee, Bombay: Oxford University Press.

Dutt, A.K. (1995): Internal finance and monopoly power in capitalist economies: a reformulation of Steindl's growth model, Metroeconomica, 46: 16-34.

Dutt, A.K. (2005): Steindl's theory of maturity and stagnation and its relevance today, in: Mott, T., Shapiro, N. (eds.), Rethinking Capitalism. Essays on the Economics of Josef Steindl, London, New York: Routledge. 
Dutt, A.K. (2010): Equilibrium, stability and path dependence in Post Keynesian models of economic growth, in: Birolo, A., Foley, D., Kurz, H.D., Steedman, I. (eds.), Production, Distribution and Trade: Alternative Perspectives, London: Routledge.

Eggertsson, G.B., Mehrotra, N.R. (2014a): A model of secular stagnation, NBER Working paper No. 20574.

Eggertsson, G.B., Mehrotra, N.R. (2014b): A model of secular stagnation, in: Teulings, C., Baldwin, R. (eds.), Secular Stagnations: Facts, Causes and Cures. A VoxEU.org eBook, London: Centre for Economic Policy Research (CEPR).

Flaschel, P., Skott, P. (2006): Steindlian models of growth and stagnation, Metroeconomica, 57: 303-338.

Foster, J.B. (1987): What is stagnation?, in: Cherry, R. et al. (eds.), The Imperiled Economy, Book I, Macroeconomics from a left perspective, New York: URPE.

Foster, J.B. (2014): The Theory of Monopoly Capitalism: An Elaboration of Marxian Political Economy, New York: Monthly Review Press.

Foster, J.B., McChesney, R.W. (2012): The Endless Crisis: How Monopoly-Finance Capital Produces Stagnation and Upheaval from the USA to China, New York: Monthly Review Press.

Franke, R. (2015): A supplementary note on Professor Hein's (2013) version of a Kaleckian debt accumulation, manuscript, University of Kiel.

Glaeser, E.L. (2014): Secular joblessness, in: Teulings, C., Baldwin, R. (eds.), Secular Stagnation: Facts, Causes and Cures. A VoxEU.org eBook, London: Centre for Economic Policy Research (CEPR).

Gordon, R. (2012): Is US economic growth over? Faltering innovation confronts the six headwinds, NBER Working Paper No. 18315.

Gordon, R. (2014): The turtle's progress: Secular stagnation meets the headwinds, in: Teulings, C., Baldwin, R. (eds.), Secular Stagnation: Facts, Causes and Cures. A VoxEU.org eBook, London: Centre for Economic Policy Research (CEPR).

Guger, A., Marterbauer, M., Walterskirchen, E. (2006): Growth policy in the spirit of Steindl and Kalecki, Metroeconomica, 57: 428-442.

Hansen, A.H. (1934): Capital goods and the restoration of purchasing power, Proceedings of the Academy of Political Science, 16 (1): 11-19.

Hansen, A.H. (1939): Economic progress and declining population growth, American Economic Review, 29 (1): 1-15.

Harcourt, G.C. (1969): Some Cambridge controversies in the theory of capital, Journal of Economic Literature, 7: 369-405. 
Harcourt, G.C. (1972): Some Cambridge Controversies in the Theory of Capital, Cambridge, UK: Cambridge University Press.

Harrod, R.F. (1939): An essay in dynamic theory, The Economic Journal, 49: 14-33.

Hein, E. (2006): On the (in-)stability and the endogeneity of the 'normal' rate of capacity utilisation in a post-Keynesian/Kaleckian 'monetary' distribution and growth model, Indian Development Review, 4: 129-150.

Hein, E. (2008): Money, Distribution Conflict and Capital Accumulation. Contributions to 'Monetary Analysis', Basingstoke: Palgrave Macmillan

Hein, E. (2010): Shareholder value orientation, distribution and growth - short- and mediumrun effects in a Kaleckian model, Metroeconomica, 61: 302-332.

Hein, E. (2011): Redistribution, global imbalances and the financial and economic crisis - the case for a Keynesian New Deal, International Journal of Labour Research, 3 (1): 51 73.

Hein, E. (2012a): The Macroeconomics of Finance-dominated Capitalism - and its Crisis, Cheltenham: Edward Elgar.

Hein, E. (2012b): 'Financialisation', distribution, capital accumulation and productivity growth in a post-Kaleckian model, Journal of Post Keynesian Economics, 34: 475496.

Hein, E. (2013): On the importance of the retention ratio in a Kaleckian distribution and growth model with debt accumulation - a comment on Sasaki and Fujita (2012), Metroeconomica, 64: 186-196.

Hein, E. (2014): Distribution and Growth after Keynes: A Post-Keynesian Guide, Cheltenham: Edward Elgar.

Hein, E., Dodig, N. (2015): Financialisation, distribution, growth and crises - long-run tendencies, in: Hein, E., Detzer, D., Dodig N. (eds.), The Demise of Financedominated Capitalism: Explaining the Financial and Economic Crises, Cheltenham: Edward Elgar.

Hein, E., Lavoie, M., van Treeck, T. (2011): Some instability puzzles in Kaleckian models of growth and distribution: a critical survey, Cambridge Journal of Economics, 35: 587612.

Hein, E., Lavoie, M., van Treeck, T. (2012): Harrodian instability and the 'normal rate' of capacity utilisation in Kaleckian models of distribution and growth - a survey, Metroeconomica, 63: 139-169.

Hein, E., Mundt, M. (2012): Financialisation and the requirements and potentials for wageled recovery - a review focussing on the G20, Conditions of Work and Employment Series No. 37, 2012, Geneva: ILO. 
Hein, E., Truger, A. (2011): Finance-dominated capitalism in crisis - the case for a Keynesian New Deal at the European and the global level, in Arestis, P., Sawyer, M. (eds), New Economics as Mainstream Economics, International Papers in Political Economy, Basingstoke: Palgrave Macmillan.

Hein, E., Truger, A. (2012/13): Finance-dominated capitalism in crisis - the case for a global Keynesian New Deal, Journal of Post Keynesian Economics, 35: 183-210.

Hein, E., van Treeck, T. (2010): 'Financialisation' in post-Keynesian models of distribution and growth - a systematic review, in Setterfield, M. (ed.), Handbook of Alternative Theories of Economic Growth, Cheltenham: Edward Elgar.

Hicks, J. (1932): The Theory of Wages, London: Macmillan.

Hobson, J.A. (1902): Imperialism: A Study, New York: James Pott \& Company.

Horn, G., Joebges, H., Zwiener, R. (2009): From the financial crisis to the world economic crisis (II). Global imbalances: Cause of the crisis and solution strategies for Germany, IMK Policy Brief, December 2009, Duesseldorf: Macroeconomic Policy Institute (IMK) at Hans-Boeckler Foundation.

ILO (2012): Global Wage Report. Wages and Equitable Growth, Geneva: ILO.

Kaldor, N. (1957): A model of economic growth, The Economic Journal, 67: 591-624, reprinted in Kaldor, N., Collected Economic Essays, Volume 2, Essays on Economic Stability and Growth, London: Duckworth, 1960.

Kaldor, N. (1961): Capital accumulation and economic growth, in: Lutz, F.A., Hague, D.C. (eds), The Theory of Capital, London: Macmillan, reprinted in Kaldor, N., Collected Economic Essays, Volume 5, Further Essays on Economic Theory, London: Duckworth, 1978.

Kaldor, N. (1966): Causes of the Slow Rate of Economic Growth in the United Kingdom, Cambridge, UK: Cambridge University Press, reprinted in Kaldor, N., Collected Economic Essays, Volume 5, Further Essays on Economic Theory, London: Duckworth, 1978.

Kalecki, M. (1937): The principle of increasing risk, Economica, 4: 440-447.

Kalecki, M. (1954): Theory of Economic Dynamics, London: George Allen and Unwin.

Kalecki, M. (1971): Selected Essays on the Dynamics of the Capitalist Economy, 1933-70, Cambridge, UK: Cambridge University Press.

Keynes, J.M. (1936): The General Theory of Employment, Interest and Money, in: The Collected Writings of J.M. Keynes, Vol. VII, London, Basingstoke: Macmillan 1973.

Keynes, J.M. (1943): The long-term problem of full employment, in: The Collected Writings of J.M. Keynes, Vol. XXVII, London: Macmillan, 1980. 
King, J.E. (1995): Outside the mainstream: Josef Steindl's Economic Papers 1941-88, Cambridge Journal of Economics, 19: 463-475.

Koo, R. (2013): Balance sheet recession as the 'other half' of macroeconomics, European Journal of Economics and Economic Policies: Intervention, 10: 136-157.

Koo, R. (2014): Balance sheet recession is the reason for secular stagnation, in: Teulings, C., Baldwin, R. (eds.), Secular Stagnation: Facts, Causes and Cures. A VoxEU.org eBook, London: Centre for Economic Policy Research (CEPR).

Krugman, P. (2014): Four observations on secular stagnation, in: Teulings, C., Baldwin, R. (eds), Secular Stagnation: Facts, Causes and Cures. A VoxEU.org eBook, London: Centre for Economic Policy Research (CEPR).

Lavoie, M. (1992): Foundations of Post Keynesian Economic Analysis, Aldershot, Brookfield: Edward Elgar.

Lavoie, M. (1995a): The Kaleckian model of growth and distribution and its neo-Ricardian and neo-Marxian critiques, Cambridge Journal of Economics, 19: 789-818.

Lavoie, M. (1995b): Interest rates in post-Keynesian models of growth and distribution, Metroeconomica, 46: 146-177.

Lavoie, M. (1996): Traverse, hysteresis and normal rates of capacity utilization in Kaleckian models of growth and distribution, Review of Radical Political Economics, 28 (4), 113-147.

Lavoie, M., Stockhammer, E. (2013a) (eds.): Wage-led Growth: An Equitable Strategy for Economic Recovery, Basingstoke: Palgrave Macmillan.

Lavoie, M., Stockhammer, E. (2013b): Wage-led growth: concept, theories and policies', in: Lavoie, M., Stockhammer, E. (eds.), Wage-led Growth: An Equitable Strategy for Economic Recovery, Basingstoke: Palgrave Macmillan.

Lazzarini, A. (2011): Revisiting the Cambridge Capital Controversies: A Historical and Analytical Study, Pavia: Pavia University Press.

Lee, F.S. (1998): Post Keynesian Price Theory, Cambridge, UK: Cambridge University Press.

Luxemburg, R. (1913): Die Akkumulation des Kapitals. Ein Beitrag zur ökonomischen Erklärung des Imperialismus, Berlin: Vorwärts, English translation: The Accumulation of Capital, London: Routledge and Kegan Paul, 1951-

Marx, K. (1867): Das Kapital. Kritik der politischen Ökonomie, Erster Band: Der Produktionsprozeß des Kapitals, $4^{\text {th }}$ edition 1890 , edited by F. Engels, reprinted as Marx-Engels-Werke, Volume 23, Berlin: Dietz Verlag 1962, englisch translation: Capital. A Critique of Political Economy, Volume 1: The Process of Capitalist Production, New York: International Publisher, 1967. 
Mazzucato, M. (2013): The Entrepreneurial State: Debunking Public vs. Private Sector Myths, London: Anthem Press.

Mazzucato, M., Penna, C.C.R. (2015): Beyond market failures: The market creating and shaping roles of state investment banks, Working Paper No. 831, Annandale-onHudson, NY: Levy Economics Institute of Bard College.

Meade, J.E. (1975): The Keynesian revolution', in: Keynes, M. (ed.), Essays on John Maynard Keynes, Cambridge: Cambridge University Press.

Mokyr, J. (2014): Secular stagnation? Not in our life, in: in: Teulings, C., Baldwin, R. (eds.), Secular Stagnation: Facts, Causes and Cures. A VoxEU.org eBook, London: Centre for Economic Policy Research (CEPR).

Mott, T., Shapiro, N. (2005) (eds.): Rethinking Capitalist Development: Essays on the Economics of Josef Steindl, London, New York: Routledge.

OECD (2015): Escaping from the Stagnation Trap: Policy Options for the Euro Area and Japan, Paris: OECD.

Palley, T.I. (2012): From Financial Crisis to Stagnation: The Destruction of Shared Prosperity and the Role of Economics, Cambridge, UK: Cambridge University Press.

Palley, T.I. (2013): Financialization: The Economics of Finance Capital Domination, Basingstoke: Palgrave Macmillan.

Robinson, J. (1962): Essays in the Theory of Economic Growth, London: Macmillan.

Rowthorn, R.E. (1981): Demand, real wages and economic growth, Thames Papers in Political Economy, Autumn: 1-39.

Sasaki, H., Fujita, S. (2012): The importance of the retention ratio in a Kaleckian model with debt accumulation, Metroeconomica, 63: 417-428.

Shaikh, A. (2009): Economic policy in a growth context: a classical synthesis of Keynes and Harrod, Metroeconomica, 60: 455-494.

Shapiro, N. (2012): Josef Steindl: an economist of his times, PSL Quarterly Review, 65: 167187.

Skott, P. (2010): Growth, instability and cycles: Harrodian and Kaleckian models of accumulation and income distribution, in: Setterfield, M. (ed.), Handbook of Alternative Theories of Economic Growth, Cheltenham: Edward Elgar.

Skott, P. (2012): Theoretical and empirical shortcomings of the Kaleckian investment function, Metroeconomica, 63: 109-138.

Steedman, I. (1977): Marx after Sraffa, London: NLB.

Steindl, J. (1952): Maturity and Stagnation in American Capitalism, Oxford: Blackwell, $2^{\text {nd }}$ edition, New York, London: Monthly Review Press, 1976. 
Steindl, J. (1964): On maturity in capitalist economies, in: Problems of Economic Dynamics and Planning: Essays in Honour of Michal Kalecki, Warsaw: PWN-Polish Scientific Publishers.

Steindl, J. (1976): Introduction, in: Steindl, J., Maturity and Stagnation in American Capitalism, $2^{\text {nd }}$ edition, New York, London: Monthly Review Press.

Steindl, J. (1979): Stagnation theory and stagnation policy, Cambridge Journal of Economics, 3, 1-14, reprinted in: Steindl, J., Economic Papers, 1941-88, Basingstoke: Macmillan, 1990 (page numbers in the text refer to the original).

Steindl, J. (1981a): Some comments on the three versions of Kalecki's theory of the trade cycle', in: Los, J. et al. (eds.), Studies in Economic Theory and Practice. Essays in Honour of Edward Lipinski, Amsterdam: North-Holland, reprinted in Steindl, J., Economic Papers, 1941-88, Basingstoke: Macmillan, 1990.

Steindl, J. (1981b): Ideas and concepts of long run growth, Banca Nazionale del Lavoro Quarterly Review, 34 (136): 35-48, reprinted in J. Steindl, Economic Papers, 1941-88, Basingstoke: Macmillan, 1990.

Steindl, J. (1985): Distribution and growth, Political Economy. Studies in the Surplus Approach, 1: 53-68, reprinted in J. Steindl, Economic Papers, 1941-88, Basingstoke: Macmillan, 1990.

Steindl, J. (1989): From stagnation in the 30s to slow growth in the 70s, in: Berg, M. (ed.), Political Economy in the Twentieth Century, Oxford: Philip Allan, reprinted in: J. Steindl, Economic Papers, 1941-88, Basingstoke: Macmillan, 1990.

Stockhammer, E. (2010): Income distribution, the finance-dominated accumulation regime, and the present crisis, in: Dullien, S., Hein, E., Truger, A., van Treeck, T. (eds.), The World Economy in Crisis - the Return of Keynesianism?, Marburg: Metropolis.

Stockhammer, E. (2012): Financialization, income distribution and the crisis, Investigación Económica, 71 (279): 39-70.

Stockhammer, E. (2015): Rising inequality as a cause of the present crisis, Cambridge Journal of Economics, 39: 935-958.

Stockhammer, E., Onaran, Ö. (2012): Rethinking wage policy in the face of the Euro crisis: Implications of the wage-led demand regime, International Review of Applied Economics, 26: 191-203.

Stockhammer, E., Onaran, Ö. (2013): Wage-led growth: theory, evidence, policy, Review of Keynesian Economics, 1: 61-78.

Summers, L.A. (2013): Remarks at IMF Economic Forum, 8 November 2013, https://www.youtube.com/watch? $\mathrm{v}=\mathrm{KYpVzBbQIX0.}$

Summers, L.A. (2014a): US economic prospects: secular stagnation, hysteresis, and the zero lower bound, Business Economics, 49 (2): 65-73. 
Summers, L.A. (2014b): Reflections on the 'New Secular Stagnation Hypothesis', in: Teulings, C., Baldwin, R. (eds.), Secular Stagnation: Facts, Causes and Cures. A VoxEU.org eBook, London: Centre for Economic Policy Research (CEPR).

Summers, L.A. (2015): Demand side secular stagnation, American Economic Review: Papers and Proceedings, 105 (5): 60-65.

Sweezy, P.M. (1942): Theory of Capitalist Development, New York: Oxford University Press.

Taylor, L. (1991): Income Distribution, Inflation, and Growth. Lectures on Structuralist Macroeconomic Theory, Cambridge, MA, London: MIT Press.

Taylor, L. (2008): Reconstructing Macroeconomics. Structuralist Proposals and Critiques of the Mainstream, New Delhi et al.: Viva Books.

Teulings, C., Baldwin, R. (2014a) (eds.): Secular Stagnation: Facts, Causes and Cures. A VoxEU.org eBook, London: Centre for Economic Policy Research (CEPR).

Teulings, C., Baldwin, R. (2014b): Introduction, in: Teulings, C., Baldwin, R. (eds.), Secular Stagnation: Facts, Causes and Cures. A VoxEU.org eBook, London: Centre for Economic Policy Research (CEPR).

UNCTAD (2009): The Global Economic Crisis. Systemic Failures and Multilateral Remedies, New York, Geneva: UNCTAD.

Van Treeck, T., Sturn, S. (2012): Income inequality as a cause of the Great Recession? A survey of current debates, Conditions of Work and Employment Series No. 39, ILO, Geneva. 